\title{
Antitrust and IPOs in the Supreme Court
}

\author{
Clark C. Havighurst \\ Wm. Neal Reynolds Emeritus Professor of Law \\ Duke University \\ [April 12, 2007]
}

\begin{abstract}
This short comment suggests a connection, so far unrecognized, between two antitrust cases currently awaiting decision by the Supreme Court. In one case, the Court is likely, though not certain, to overturn the long-standing rule that resale price maintenance is illegal per se. If that should occur, another case on the Court's docket, involving the scope of the implied antitrust immunity enjoyed by underwriters of corporate securities offerings, would (or should) look very different. This comment suggests that, if the law of vertical restraints is finally rationalized so that an issuer of a security may lawfully restrict price and other competition among its distributors, the traditional basis for inferring a congressional intention to exempt securities offerings from the Sherman Act (a "clear repugnancy" between two statutory regimes) would at least arguably disappear. Although the justices are unlikely to see the point in the pending case on underwriter immunity, there might be room for future antitrust challenges to horizontal restraints conceived and implemented by underwriters in IPOs.
\end{abstract}

On March 27, the Supreme Court heard arguments in a case questioning how much antitrust immunity the federal securities laws confer by implication on investment bankers collaborating in the underwriting of securities offerings. Although none of the briefs or arguments in that case ${ }^{1}$ so observed, another pending case, ${ }^{2}$ argued just one day earlier, could well change a basic rule of antitrust law in such a way that an antitrust exemption would no longer be needed to allow initial public offerings of securities (IPOs) to proceed efficiently and effectively. In the unlikely event that the justices connect the dots between these two cases and see the implications outlined in this comment, U.S. financial markets and the issuers of securities would benefit. Investment bankers, however, would lose much of their current ability to manage IPOs to their own, rather than the issuer's, advantage.

\footnotetext{
${ }^{1}$ Credit Suisse Securities (USA) LLC. v. Billing, U.S. Sup. Ct., Dkt. No. 05-1157 (2007).

${ }^{2}$ Leegin Creative Leather Prods, Inc.. v. PSKS, Inc., U.S. Sup. Ct., Dkt. No. 06-480 (2007).
} 
In the first-argued of the two cases, the Court has what should be a welcome opportunity to overrule the well-known $\mathrm{Dr}$. Miles case, ${ }^{3}$ a 1911 decision in which some highly artificial reasoning produced the rule that a seller of a product may under no circumstances fix its dealers' resale prices. That case's relevance to IPOs arises because restrictions on competition among participating underwriters may be either "vertical" or "horizontal." That is, they may either be imposed on the underwriters by the issuer of the securities or result from an agreement among the underwriters themselves. If the issuer itself sets the price at which its underwriters are required to resell, it would be a clear instance of resale price maintenance (RPM) - precisely what the Dr. Miles case condemned.

The rule against RPM has been applied over the years only to the marketing of branded consumer products like Dr. Miles' patent medicines. But there is no reason in antitrust logic why it would not apply equally to the marketing of a particular issuer's securities. ${ }^{4}$ Not only is a security a similarly distinctive product, but underwriters, despite their elite status, are no different for antitrust purposes from ordinary retailers. In any event, the possibility that antitrust law's prohibitions of price fixing and other restrictions on competition might interfere with IPOs has long supported an assumption that Congress expects only the securities laws to govern underwritings. And no one participating in the Supreme Court argument of the IPO case suggested that an overruling of Dr. Miles, if it should occur, might be a reason to reconsider whether any antitrust exemption for IPOs is really necessary. Yet if the Court does finally rationalize the law of vertical price fixing, the legal prerequisite for inferring an antitrust exemption for IPO arrangements - a "clear repugnancy" between antitrust law and the regulatory scheme ${ }^{5}$ would arguably disappear.

On the other hand, the IPO example itself clearly shows why the Dr. Miles rule should be overturned. There are very convincing business reasons why an issuer might

\footnotetext{
${ }^{3}$ Dr. Miles Medical Co. v. John D. Park \& Sons Co., 220 U.S. 373 (1911).

${ }^{4}$ See generally Havighurst, "Antitrust Law: Cases Before High Court," National Law Journal, Jan. 15, 2007, p. 7 (explaining how the result in a 1953 antitrust case upholding underwriters' anticompetitive arrangements, United States v. Morgan, 118 F. Supp. 621 (S.D.N.Y. 1953), can be justified only by recognizing the vertical nature of price fixing in an IPO and the legitimacy of such RPM).

5 "Implied antitrust immunity is not favored, and can be justified only by a convincing showing of clear repugnancy between the antitrust laws and the regulatory system." United States v. National Ass' $n$ of Securities Dealers, 422 U.S. 694, 719-20 (1975).
} 
instruct its underwriters, which bear substantial financial risks in any event, not to engage in competitive price cutting in selling their IPO allotments. This example alone is enough to show that a blanket prohibition of RPM makes no economic sense. Yet no one arguing that the Supreme Court got it wrong in 1911 has thought to cite the logic and efficiency of RPM in the marketing of corporate securities as proof that restricting dealer price competition can be a perfectly legitimate strategy in marketing a distinctive product. As long as the larger ("interbrand") market is vigorously competitive (as the market for investments clearly is), providing price protection in the "intrabrand" market is simply an efficient way for a seller to attract good dealers and to compensate them for working successfully on its behalf.

It is also customary in IPOs to restrict various forms of non-price competition in order to facilitate a smooth distribution. At one time, antitrust law was just as hostile to vertically imposed non-price restraints as it was to vertical price fixing. In a series of cases over the last thirty years, however, the Supreme Court has greatly expanded the ability of producers of consumer products to control their dealers' competitive efforts, even when price competition among them was significantly curtailed. ${ }^{6}$ Although some justices' questions at oral argument of the RPM case suggested a continued attachment to the now-anomalous rule of $\mathrm{Dr}$. Miles, there is every reason why RPM, clearly the best strategy available for effectively marketing certain products (including corporate securities), should receive the same sympathetic treatment as vertical non-price restraints.

If the Supreme Court were now to decide that vertical price fixing may sometimes be defensible under antitrust law's rule of reason, the need for an antitrust exemption for anticompetitive arrangements in an IPO would be far from clear. In applying the rule of reason, a court would view a securities underwriting as an arguably procompetitive joint

\footnotetext{
${ }^{6}$ E.g., Continental T.V., Inc. v. GTE Sylvania Inc., 433 U.S. 36 (1977); Monsanto Co. v. Spray-Rite Serv. Corp., 465 U.S. 752 (1984); Business Electronics Corp. v. Sharp Electronics Corp., 485 U.S. 717 (1988). These rulings all rested on the crucial insight that it is interbrand, not intrabrand, competition that protects consumers' essential interests. Indeed, the Court has acknowledged in dicta that the Dr. Miles per se rule against RPM is theoretically defensible, if at all, only because of the possibility that vertical price fixing may sometimes be used to harm interbrand competition. Continental T.V., 433 U.S. at 52 n. 18; Business Electronics, 485 U.S. at 725-26. In general, the Court has endorsed the notion that, where interbrand competition is healthy, a manufacturer should not be prevented by antitrust law from implementing a marketing strategy that serves its competitive interests even if, in so doing, it significantly curtails price and other forms of competition among its dealers.
} 
venture between the issuer and dealers it selects, analyzing the venture's inevitable restraints on competition among the underwriters only to ensure their validity as ancillary restraints facilitating the larger distribution effort. The analysis would begin by recognizing the issuer's legitimate, procompetitive interest in controlling how its securities are marketed, so as to maximize the proceeds to itself and minimize any dilution of its shareholders' interests. The other side of this coin, of course, would be that investment bankers would face potential antitrust liability for anticompetitive arrangements originating from their own horizontal agreements, not with the issuer itself. But an antitrust exemption is called for, presumably, only if it is necessary to facilitate the marketing of securities, not to protect underwriters as such or their anticompetitive agreements. Although competitor collaboration in joint ventures can often be justified on efficiency grounds, a court could reasonably hold (under the rule of reason's "lessrestrictive-alternative" requirement) that underwriters in an IPO must submit to the issuer's control rather than controlling competition-sensitive matters themselves.

Unfortunately, distinguishing between vertical and horizontal restraints is not always easy. Issuers naturally seek and take their underwriters' advice on many matters, and there should be no antitrust obstacle to such normal cooperation. But an issuer's ability to control its own offering would be in jeopardy if its underwriters are in a position to dictate details of the offering, including the offering price. There are reasons to doubt that today's market for underwriters' services is competitive and unregulated enough to give issuers a truly free hand in selecting and controlling their underwriters. ${ }^{7}$ If the market's invisible hand is weak, then investment bankers may have the upper one which, if they exercise it, could get them into antitrust trouble. Good legal advice, if they follow it, should protect them, however. Unwarranted lawsuits should be subject to summary judgment on a clear showing that the issuer, perhaps with independent advice, approved the marketing plan.

The felt need to infer antitrust exemptions for restrictions on underwriter competition in IPOs originally arose because antitrust law posed a potential threat to the orderly marketing of securities, by seeming to call into question any restrictions on

\footnotetext{
${ }^{7}$ Interestingly, the government also questioned (unsuccessfully) the competitiveness of the market for investment bankers' services in United States v. Morgan, 118 F. Supp. 621 (S.D.N.Y. 1953) (see note 4 supra).
} 
competition between members of an underwriter group. However, removal of the $D r$. Miles rule, under which sellers of distinctive products are flatly prohibited from prescribing their dealers' resale prices, would finally enable courts applying the antitrust laws to securities underwriters to take the issuer's point of view. The courts' goal should then be to allow issuers, rather than the underwriters acting in their own interest, to determine which restraints will be helpful in marketing their securities in competition with other securities in a highly competitive "interbrand" market. Not only would antitrust law, so applied, enhance the ability of corporations to raise capital and the overall efficiency of capital markets, but the goals and substance of antitrust law would become congruent with the goals and substance of the nation's securities laws. There would no longer be a judicially noticeable need for an antitrust exemption to protect the delicate process of securities marketing from disruption by misguided antitrust courts. An antitrust exemption for securities underwriters engaged in IPOs would no longer be necessary to make the SEC's regulatory scheme for securities underwritings (and the underwriting syndicates it contemplates) "work."8

In the pending IPO litigation, some important underwriters are seeking to avoid antitrust liability for collectively using their power over shares in heavy demand during the dot-com boom to manipulate prices in the aftermarket. Their argument is that antitrust oversight is not needed or appropriate because the SEC has authority to police any objectionable conduct. The manipulations in question - so-called "tie-ins" and "laddering" practices - were particularly egregious, however, and occurred on the SEC's watch, suggesting that stronger sanctions may be needed. The specific restraints alleged were decidedly not the kind that issuers would be likely to approve.

In any event, the Supreme Court is practically certain to decide the pending IPO case on the narrow grounds on which it was argued, either extending or not extending the investment bankers' antitrust exemption for IPOs but not raising at all the question of the exemption's continued legitimacy. This would be ironic if simultaneously, after 96 years in error, the Court were finally to acknowledge that a producer of a unique product has, under normal competitive circumstances, a legitimate interest in controlling all aspects of

\footnotetext{
${ }^{8}$ See Silver v. New York Stock Exchange, 373 U.S. 341, 357 ("Repeal is to be regarded as implied only if necessary to make the Securities Exchange Act work, and even then only to the minimum extent necessary.").
} 
its marketing. Certainly, the issuer of a security is a far more appropriate party than either the SEC or the underwriters themselves to decide how much competition should be restricted in marketing it. If the Dr. Miles rule is overturned, a later case may challenge the need for a continuing antitrust exemption for IPOs - unless, of course, the investment bankers get to Congress first.

Defenders of IPO underwriters' antitrust immunity in the Supreme Court have argued that the strength and attractiveness of U.S. capital markets require that immunity be very broad. A more persuasive argument might be that capital markets would be more efficient and more attractive to issuers if, because of American antitrust law, the issuers themselves, and not their underwriters, could effectively control the marketing of their securities. 